\title{
Studiu canonico-istoric al dezvoltării parohiei
}

\section{Calinic DRĂGHICI*}

Abstract: The organization of the first Christian communities is less known. The overall structure of the organization, starting from the promptings of St. Ap. Paul, are few and nonexistent. Later, the community seems led by his shepherd, bishop, helped by an elder. Starting with the first canonical-liturgical documents, things are becoming clearer. The 19 th century has left the parish a clearer picture very well organized and structured. The Parish becomes a well-defined territory with its own clergy, faithful parishioners forming the parishiers, because the church becomes a place of their piety and of the most important acts in human life: the baptism, wedding and funeral. The religious life takes place around the parish. The bishop, bishop's residence and the services they can provide are away. In this regard, intermediate structures are needed, above all, the need in creation of parishes within the diocese.

Keywords: Church, community, diocese, parish clergy, faithful.

\footnotetext{
* PhD Candidate, Faculty of Orthodox Theology at "Aurel Vlaicu" University in Arad, Romania.
} 


\section{Factorii istorici care au pregătit apariția parohiei}

Ca loc de întâlnire și de comuniune a omului cu Dumnezeu, Biserica își are obârșia pământeană în Rai ${ }^{1}$. Aceasta a fost orânduită în Sfatul cel din veșnicie al lui Dumnezeu, așa încât obârșia Bisericii, mai veche decât obârșia lumii, se află în cugetarea și voia veșnică ale lui Dumnezeu: „Căci spre aceasta ne-a și făcut, ca «să ne facem părtași dumnezeieștii firi» (II Petru 1,4) și ai veșniciei Lui și să ne arătăm asemenea Lui prin îndumnezeirea cea din har, pentru care sunt toată existența și durata celor ce sunt și aducerea la ființă și nașterea celor ce nu sunt"?.

Hristos întemeiază Biserica în mod principial ca substanță și conținut al Trupului Său, și Se face Cap al ei (cf. I Corinteni cap. 12). În acest sens Sfântul Grigorie Sinaitul scoate în evidență importanța pe care o are cuvântul lui Hristos pentru noi: „Cuvântul s-a dat spre bucuria fiecărei firi raționale, asemenea unor mâncăruri felurite, sufletul simte plăcerea cuvintelor, primindu-le în chip felurit. Cuvântul cunoștinței îl are ca pe un pedagog, care-i modelează purtările, pe al citirii, ca pe unul care-1 adapă ca o haină a odihnei (Ps. 22, 3); pe al faptei, ca pe un loc de verdeață (Ps. 22, 2), care-1 îngrașă; pe al harului, ca pe un pahar care-l îmbată (Ps. 22, 5) și-l veselește (Ps. 103, 19); iar bucuria negrăită a harului, ca pe un untdelemn care veselește fața (Ps. 103, 7) și o face strălucitoare"3.

Astfel, principiul subliniat de Sfântul Irineu privind o Euharistie și un episcop în fiecare Biserică corespunde unei realități istorice. De asemenea şi unitatea euharistică originală era strict centrată în episcop, cu implicațiile aferente formării Bisericii catolice. Însă odată cu apariția parohiei s-a marcat împărțirea definitivă a Euharistiei

\footnotetext{
${ }^{1}$ Filaret al Moscovei, Catehism ortodox, București, Ed. Sophia, 2007, p. 105. ${ }^{2}$ A se vedea Sf. Maxim Mărturisitorul, Epistole, 24, PG 91, 609C, Epistole, 43, 640B, în românește, PSB, vol. 81, Scrieri, Partea a doua, p. 163.

${ }^{3}$ Sfântul Grigorie Sinaitul, Ale celui între sfinți părintelui nostru Grigorie Sinaitul. Capete foarte folositoare in acrostih, în „Filocalia”, vol. VII, Traducere, introducere și note de pr. prof. Dumitru Stăniloae, București, EIBMBOR, 1977, p. 123.
} 
originare, unite, centrată în episcop în mai multe Euharistii centrate în presbiteri.

Dar cum a fost pregătită calea pentru parohie și când a apărut aceasta în istorie? La această întrebare, fundamentală pentru istoria unității bisericești, răspunsul nu a fost dat încă. În manualele existente privind istoria bisericească și cultul, originile parohiei nu sunt tocmai clare. V. Stephanidis oferă ca primă dovadă în ceea ce privește parohiile întemeierea, în Roma, a 25 de parohii de Marcel al Romei, în anul 300. Totuși, cu siguranță nu Marcel este cel care a introdus instituția parohiilor. Despre perioada de dinainte de Marcel, Stephanidis se limitează la a afirma că, ,pe măsură ce creștea comunitatea creștină, s-au format mai multe adunări bisericești (parohii), având propriii presbiteri și diaconi, care depindeau de unul și același episcop”. Dar această observație generală nu luminează deloc originile parohiei. Astfel, întreaga problemă a originii parohiei, care privește în mod direct și esențial studiul nostru, rămâne deschisă4

Trecerea de la „o singură Euharistie aflată sub conducerea episcopului" către mai multe parohii conduse de presbiteri este clar descrisă în izvoarele primelor patru secole. Acest lucru este demonstrat mai ales de schimbarea observată în izvoare privind poziția și responsabilitatea episcopului și a presbiterilor în cadrul dumnezeieștii Euharistii. Pentru a putea înțelege această schimbare, este necesar să analizăm poziția episcopului și a presbiterilor în cadrul dumnezeieștii Euharistii potrivit, mai întâi, celor mai vechi surse și, apoi, celor mai noi ${ }^{5}$. Pentru ca presbiterul să fie legat permanent și individual de o comunitate eclesială-parohie particulară într-o așa manieră încât să fie recunoscut ca ,preot” al ei, aceasta însemnând cel care oferă dumnezeiasca Euharistie în numele parohiei, a fost necesară o lungă pregătire ce a acoperit aproape întreaga perioadă a

\footnotetext{
${ }^{4}$ Ioannis Zizioulas Mitropolit al Pergamului, Euharistie, Episcop, Biserică, București, Ed. Basilica a Patriarhiei Române, 2009, pp. 191-192.

${ }^{5}$ Ibidem, p. 193.
} 


\section{Calinic DRĂGHICI}

primelor trei secole 6 .

Apariția și stabilirea mai multor parohii în cadrul fiecărei Biserici ridică o întrebare fundamentală pentru cercetarea istorică: ce s-a întâmplat cu conștiința inițială a Bisericii conform căreia singura Euharistie „sub conducerea episcopului” întruchipează și exprimă unitatea Bisericii lui Dumnezeu aflată într-un anumit loc, acum când, din cauza numeroaselor parohii, membrii acestei Biserici au încetat să se mai adune la o singură Euharistie? Această întrebare introduce problema fundamentală a relației dintre unitatea parohială și unitatea diocezei episcopale, așa cum era aceasta percepută în Biserica primară. În ce măsură apariția parohiei a creat un fel de unitate euharistică independentă în cadrul unității diocezei?

Este foarte dificil să răspundem la această întrebare. Izvoarele existente conțin prea puține indicii sistematice sau teoretice în vederea soluţionării acestei probleme. De aceea, ne vedem obligați să extragem mărturia necesară rezolvării ei din practica și viața Bisericii primelor veacuri. Prin interpretarea corespunzătoare a acestei mărturii încercăm să analizăm mai jos în ce măsură era legată adunarea euharistică parohială de adunarea euharistică episcopală 7 . Se evidențiază faptul că, la apariția sa în istorie, parohia nu reprezenta o unitate euharistică independentă, ci doar o prelungire a Euharistiei episcopale, destinată să facă față cumplitelor nevoi practice ${ }^{8}$.

\section{Noțiunea de Biserică locală}

În primul ei înțeles, ekklèsia desemnează o adunare locală9, acolo unde creștinii se adună să primească învățătura Apostolilor, să frângă pâinea, în comuniune, și să laude pe Dumnezeu (Fapte 2, 42-

\footnotetext{
${ }^{6}$ Ibidem, p. 211.

${ }^{7}$ Ibidem, p. 223.

${ }^{8}$ Ibidem, p. 226.

9 Jean-Claude Larchet, Biserica, Trupul Lui Hristos, I Natura și structura Bisericii, București, Ed. Sophia, 2013, p. 14.
} 
47). Pentru a putea înțelege organizarea Bisericii primare, dar și pe cea a Bisericii Ortodoxe de-a lungul istoriei sale, și concepția acesteia despre Biserică, noțiunea de „Biserică locală” ${ }^{10}$ este fundamentală.

Acest termen înseamnă, pe de o parte, că ea este legată geografic de un anume loc, iar pe de altă parte, că ea îi cuprinde pe toți creștinii din acel loc, indiferent de vârstă, sex, condiție socială, origine etnică ${ }^{11}$, etc.

În Sfânta Scriptură sunt menționate locurile în care au fost întemeiate și unde existau primele Biserici: „Biserica din Ierusalim” (Fapte 8, 1; 11, 22), „Biserica din Antiohia” (Fapte 13, 1), Biserica din Cezarea (Fapte 18, 22), Biserica din Chenhrea (cf. Romani 16, 1), „Biserica lui Dumnezeu care este în Corint” (I Corinteni 1, 2; II Corinteni 1, 1), „Biserica Laodicenilor” (Coloseni 4, 16), „Biserica Tesalonicenilor” (I Tesaloniceni 1, 1; II Tesaloniceni 1, 1), „Biserica din Efes” (Apocalipsa 2, 1), „Biserica din Smirna” (Apocalipsa 2, 8), „Biserica din Tiatira” (Apocalipsa 2, 18), „Biserica din Pergam” (Apocalipsa 2, 12), „Biserica din Sardes” (Apocalipsa 3, 1), „Biserica din Filadelfia” (Apocalipsa 3, 7), „Biserica din Laodiceea” (Apocalipsa 3, 14).

Dimensiunea universală a fiecărei Biserici, adică faptul că în ea sunt cuprinși toți creștinii de orice origine, condiție și stare, este și ea menționată în Sfânta Scriptură (cf. I Corinteni 12, 12-30). Putem observa că termenul de „Biserică”, atunci când se referă la o cetate, este întotdeauna folosit la singular; la plural este folosit numai atunci când este vorba de o zonă geografică ce se întinde dincolo de hotarele cetății, adică de o regiune („Bisericile din Galatia”, I Corinteni16, 1; Galateni 1, 2; „Bisericile din Asia”, I Corinteni 16, 19; „Bisericile din Macedonia”, I Corinteni 8, 11; „Bisericile Iudeii”, Galateni 1, 22; „,cele șapte Biserici care sunt în Asia”, Apocalipsa 1, 4). Aceasta înseamnă - potrivit principiilor ecleziologiei creștine originare, așa cum pot fi ele deduse din aceste indicații - pe de o parte că nu putem

${ }^{10}$ Ibidem, p. 123.

${ }^{11}$ Gheorghios D. Metallinos, Parohia - Hristos în mijlocul nostru, Sibiu, Deisis, 2004, pp. 13-14. 
avea mai multe Biserici într-unul și același loc, iar pe de altă parte că nu putem avea Biserici pe categorii de persoane (definite potrivit criteriilor precedente).

Acest dublu principiu pare să fie legat de faptul că Biserica este privită în primul rând ca adunare euharistică (cf. Corinteni 11, 17-34; Fapte 2, 42-47), iar unde este Euharistia, acolo este trupul lui Hristos, așadar Biserica în plenitudinea ei ${ }^{12}$. Sfânta Scriptură vorbește în mai multe rânduri de Biserici ,adunate” în case particulare (cf. Coloseni 4, 15). Lucrul acesta nu indică Biserici de casă în sensul propriu al cuvântului (adică Biserici care să aparțină unei familii și în care nu s-ar aduna decât membrii ei), ci de faptul că adunarea euharistică se ținea în case puse la dispoziția comunităților locale de familii-gazde (cf. Romani 16, 23). Acest tip de Biserici de casă se pare să fi existat până în veacul al II-lea.

Adunarea euharistică ce constituia Biserica locală era întotdeauna prezidată, în Biserica primară, de un prezbiter-episcop (al cărui rol principal era acela de a săvârși Euharistia, împreună cu slujirea Tainelor și propovăduirea), înconjurat de un sobor de prezbiteri $^{13}$.

\section{Termenul de Parohie}

Informațiile oferite de izvoare arată că unitatea puternică existentă între creștinii din întreaga lume se manifestă în mod necesar prin Biserica locală. Niciun credincios creștin nu putea participa la unitatea Bisericii din lumea întreagă dacă nu aparținea mai întâi unității unei anumite Biserici locale. Aceasta dă naștere la problema fundamentală a relației existente, atât ecleziologic, cât și canonic, între unitatea Bisericii locale și cea a Bisericii din întreaga lume.

12 Jean-Claude Larchet, Biserica, Trupul Lui Hristos, I Natura și structura Bisericii, București, Ed. Sophia, 2013, p. 124.

${ }^{13}$ În acest scop a se vedea Nicolae Afanasieff, L'Eglise $d u$ Saint-Esprit, Paris, 1975, pp. 239-298. 
După cum mărturisește Sfântul Ignatie, chiar de la începutul secolului al II-lea, exista conștiința faptului că ,episcopii care sunt la marginile pământului sunt în cugetul lui Iisus Hristos". Acest lucru are o importanță deosebită pentru unitatea Bisericii din lumea întreagă, fiind expresia acestei unități prin instituirea sinoadelor.

Prima referință istorică a termenului „enorie” (parohie) provine dintr-o scrisoare a Sfântului Grigorie al Nyssei (secolul IV) către Flavian: „Și cineva a făcut cunoscut că el petrece în enoria din munte"14. Acest text face o distincție între ,enoria” și „,ekklesia”, pe care o identifică cu episcopia. $\mathrm{Cu}$ sensul de mică zonă unde locuiesc creştini, termenul se întâlnește în aceeași epocă și la Sfântul Epifanie al Salaminei Ciprului: „Care locuiește în enoria ierusalimiteană Elevteropolis, dincolo de Hebron”"15. Ceea ce astăzi se numește „enoria” se exprimă în Noul Testament cu termenul „ekklesia”, fiindcă abia mai târziu s-a realizat fragmentarea unei Biserici locale sub conducerea unui episcop în „enorii” aflate sub conducerea unor prezbiteri.

În realitatea ortodoxă, cea mai mică unitate a vieții bisericești este enoria (parohia). Ca adunare (sinaxă) euharistică a credincioșilor, orice parohie apare - desigur în strânsă legătură cu episcopia de care aparține în mod organic - ca „Biserică catolică” într-un loc și timp concret $^{16}$. În primele veacuri creștine Biserica dintr-un loc (biserica „,dintr-o casă") se identifica cu parohia. Dumnezeiasca Euharistie era episcopocentrică, cu participarea la aceasta a întregului cler local (a episcopului, prezbiterilor și diaconilor). Unitatea aceasta nu va fi însă perturbată atunci când, începând cu sfârșitul secolului II, din rațiuni mai ales practice, la periferia episcopiei vor apărea parohiile, care vor fi prezbiterocentrice, dar ele se vor crea într-o legătură indisociabilă cu episcopul. Prin episcopocentrismul parohiei se va păstra, în acord cu

\footnotetext{
${ }^{14} \mathrm{PG} 46,1001 \mathrm{~A}$.

${ }^{15} \mathrm{PG} 41,677 \mathrm{C}$.

${ }^{16}$ Gheorghios D. Metallinos, Parohia - Hristos în mijlocul nostru, Sibiu, Deisis, 2004, p. 9.
} 
învățătura Sfântului Ignatie Teoforul, și hristocentralitatea ei.

Trebuie spus însă că parohia n-a apărut ca substituit al Bisericii episcopocentrice originare, fiindcă aceasta din urmă s-a continuat în episcopia veacurilor ulterioare. În Ortodoxie, episcopia (episcopul) rămâne întotdeauna centrul vieții bisericești. Parohia nu este o nouă (altă) Biserică, astfel încât în fiecare episcopie să fie mai multe Biserici (particulare). Parohiile n-au fost înțelese niciodată ca unități euharistice independente în interiorul episcopiei, ci numai „ca ramuri organice ale ei” (mitropolitul Ioannis Zizioulas al Pergamului). Prezența episcopului în dumnezeiasca Euharistie locală nu va înceta niciodată să fie considerată indispensabilă în sinaxa euharistică a fiecărei parohii. De aceea, la fiecare dumnezeiască Euharistie episcopul e pomenit îndată după sfințirea Cinstitelor Daruri („,Intâi pomenește Doamne...”) ca și cum ar fi prezent cu trupul la sinaxă. De altfel, orice preot săvârșește Liturghia împreună cu întreaga sinaxă a credincioșilor în locul episcopului.

Euharistia episcopocentrică n-a dispărut deci în secolul II, odată cu nașterea parohiei, ci, conform mitropolitul Ioannis al Pergamului, acum se realizează ,împărțirea colegiului prezbiteriului”, pentru abordarea practică a nevoilor trupului Bisericii care creștea numeric. Parohia devine astfel e extensiune a unicei Euharistii săvârșite sub conducerea episcopului în limitele geografice ale episcopiei, fără să se creeze noi centre de unitate euharistică ${ }^{17}$.

Termenul de parohie, intrat odată în uz, se menține aproape de-a lungul întregului mileniu dintâi al erei creștine cu același înțeles, și se împarte cam din aceeași vreme în două categorii, enorii de la oraș sau urbane și enorii de la țară sau rurale. La începutul secolului al IV-lea, această distincție este consemnată inclusiv în canoane (Canonul 13 Neocezareea), firește că după tipul de enorii erau numiți și preoții sau prezbiterii, fie prezbiteri orășenești sau de cetate, fie rurali sau rustici, de la țară.

${ }^{17}$ Ibidem, p. 15. 
Inițial toate parohiile episcopale erau complet independente unele de altele și nu cunoșteau nici o autoritate din afară superioară prezbiterului propriu-zis. Cu timpul însă, mai multe unități de acest fel s-au constituit în organizații superioare și anume în unități teritoriale conduse de mai mulți episcopi, în frunte cu un protos, adică un primat sau întâistătător. Aceste unități apar din veacul II și se mențin timp îndelungat (Canonul 34 Apostolic).

În mod practic, prin organizarea unităților sale principale în cadrul unităților locale și teritoriale ale organizației de stat, Biserica și-a creat o normă sau un obicei căruia i s-a dat apoi expresie formală, prin legile sale proprii, adică prin canoane, și a fost ridicat la rangul unui principiu canonic de bază, pentru organizarea Bisericii. Acesta este principiul teritorial, căruia i se dă expresia cea mai clară în canoanele 17 Sinodul IV ecumenic și 38 Sinodul VI ecumenic al căror cuprins este următorul:

„Parohiile de la țară, sau cele de prin sate din fiecare eparhie să rămână nestrămutate la episcopii, care le dețin, și mai ales dacă leau administrat ținându-le fără opoziție timp de 30 de ani. Iar dacă în cuprinsul celor 30 de ani s-au născut sau s-ar naște vreo controversă pentru acestea, se permite celor ce zic că au fost nedreptățiți să se adreseze la sinodul Eparhiei. Iar dacă cineva s-ar nedreptăți de mitropolitul său să se judece la exarhul diecezei sau la scaunului Constantinopolului, precum s-a zis mai înainte. Iar dacă vreo cetate s-a înnoit prin puterea împărătească sau se va înnoi în viitor, apoi și împărțirea parohiilor bisericești să urmeze alcătuirilor civile și de Stat”.

Ca o comunitate-comuniune realizată, parohia a fost în toată istoria Bisericii modelul eclezial de organizare și viață socială. În cadrul parohiei bisericești relațiile interpersonale se formează într-un mod care diferă de cel al lumii. 


\section{Calinic DRĂGHICI}

\section{Concluzii}

Biserica nu se limitează doar la critica situației sau la propuneri deontologice de tot felul, adică doar la cuvinte. Cu Hristos extins de-a lungul veacurilor, Biserica nu distribuie aspirine pentru dureri de cap ale lumii, ci oferă o vindecare permanentă și definitivă problemelor lumii.

Chemarea Bisericii lui Hristos adresată lumii nu e o invitație universală la o idee (,ia și citește”, cum va spune Fericitul Augustin), ci o chemare la o existență, la o realitate vie. De aceea, ea se exprimă în cuvintele evanghelice cunoscute: „Vino și vezi!” (Ioan 1, 46). Aceasta înseamnă o chemare la o viață diferită de viața lumii. De aceea și diaconul Ștefan a fost acuzat de farisei că vrea să schimbe „datinile" pe care le-a dat Moise (F. A. 6, 14). Întrucât El chema la viața „,creației celei noi”. Biserica și unitatea ei mai mică, care este parohia, trebuie să rămână „o creație nouă” ca să ofere cu adevărat viața harului, Ortodoxia.

\section{Bibliografie}

1. Afanasieff, Nicolae, L'Eglise du Saint-Esprit, Paris, 1975.

2. Filaret al Moscovei, Catehism ortodox, București, Ed. Sophia, 2007.

3. Larchet, Jean-Claude, Biserica, Trupul Lui Hristos, I, Natura și structura Bisericii, București, Ed. Sophia, 2013.

4. Metallinos, Gheorghios D., Parohia - Hristos in mijlocul nostru, Sibiu, Deisis, 2004.

5. PG 46, 1001A.

6. $\mathrm{PG} 41,677 \mathrm{C}$.

7. Sf. Maxim Mărturisitorul, Epistole, 24, PG 91, 609C, Epistole, 43, 640B, în românește, PSB, vol. 81, Scrieri, Partea a doua.

8. Sf. Grigorie Sinaitul, Ale celui între sfinți părintelui nostru Grigorie Sinaitul. Capete foarte folositoare in acrostih, în „Filocalia”, vol. VII, traducere, introducere și note de pr. prof. Dumitru Stăniloae, București, EIBMBOR, 1977.

9. Zizioulas, Ioannis Mitropolit al Pergamului, Euharistie, Episcop, Biserică, București, Ed. Basilica a Patriarhiei Române, 2009. 